\title{
XVI. On some Beds of Shell-Marle in Scotland.
}

\author{
By HENRY WARBURTON, Esq. F.R.s.
}

VICE PRESIDENT OF THE GEOLOGICAL SOCIETY.

[Read January 21st, 1814.]

IHE late researches of Messrs. Cuvier and Brongniart in the vicinity of Paris, and those of Mr. Webster in the Isle of Wight, have made known to us a new series of beds, of which the most remarkable consist almost entirely of the shells of freshwater molluscæ. An instance of analogous recent accumulations will not, I hope, be undeserving of the Society's attention.

The Rev. James Lambert, of Trinity College, Cambridge, has supplied me with most of the following particulars, which have been chiefly abstracted from the returns made to that gentleman's enquiries by some respectable land agents and proprietors in the neighbourhood of Dundee.

The beds of shell-marle are chiefly found in the shire of Angus, in the several parishes of Kerrymuir, Airlie, Forfar, Rescobie, Meigh, Newtigh, Abermo', and Lundie, lying from eight to twenty miles north-west or north-east of Dundee. They are also known in the shires of Perth and Ross, and south of the Tay in the shire of Fife near to St. Andrew's, and of Berwick near to Kelso.

The shells, which, by the kindness of Mr. Lambert, I am enabled to present to the Society, were taken from a bed of marle lying on 
the estate of Mr. Cleghorn, about four miles south of St. Andrew's. This bed is found in a piece of swampy ground, at the bottom of a natural hollow, in attempting to drain which the marle was discovered. It is entirely covered by moss, and also rests upon moss, of which a specimen, taken from beneath the marle, accompanies the shells. In the middle of this hollow the marle is five feet thick.

Logie lies in the parish of Kerrymuir, between Glamis and Forfar. The following succession of beds has been discovered on cutting trenches for obtaining the peat mosses. Moss, containing trees, from four to six feet thick; shell marle, from six to seven feet; blue clay; shell marle, nine inches thick; gravel or quick sand, and sometimes a third bed of marle.

These beds of marle are continuous, and extend over many acres; they are thickest in the middle, and become gradually thinner towards the edges of the bogs.

The marle of Logie, as well as that from Fifeshire above described, consists almost entirely of the shells of the Helix putris, such as are the specimens presented: myriads of this species are now found living in the brooks that flow through the bogs of Logie. Living specimens of the Mytilus cygneus, equal in dimensions to those mentioned by Montagu, and occasionally containing fine pearls, are found in the same brooks: of this shell the marle also contains fragments.

Not far from Logie, in the parish of Forfar, are the moss and loch of Resteneth, which about the year 1794 were entirely drained by a cut made into the loch of Rescobie, lying at the distance of half a mile on a lower level. Both the moss and loch contain shell marle: that in the moss is covered to the depth of five or six feet by fine black peat, that in the loch not unfrequently so. The marle does not lie in a horizontal bed, but shelves from 
Mr. WARBURTON on Shell-Marle.

the middle of the loch, where it is eleven feet thick, to the edges of the moss, where it does not exceed in thickness a few inches.

The marle of Resteneth consists of the shells belonging to the Helix putris (Pennant), (peregra Montagu), and the Cardium amnicum (Mont.), both which are now found living in the waters that flow through the loch. Neither of these in size much exceed a pea; yet not less than two millions of cubic feet of marle had been dug between the years 1794 and 1807 for agricultural purposes.*

Resteneth loch lies about twelve miles distant from the sea at the level of 196 feet above low water mark. It gives rise to a considerable stream, which flows into the sea about thirteen miles east of the loch, after forming in the three first miles of its course the lochs of Rescobie, Balgarvie and Balmodin, in all which shell marle is obtained by dredging with boats ; in the loch of Rescobie at the depth of 25 fathoms.

Lord Duncan's loch is situated in the parish of Lundie, eight or nine miles north-west of Dundee. It covers an area of seventy acres, of which fifty have been drained, and from which shell marle is dug, as in that of Resteneth.

In all these places we have the same appearances; the marle always occupying some natural hollow or basin, which either is or has been the site of a pool of water. In Resteneth loch we have

* The shell marle in an economical point of view is of some importance. On the estate of Mr. Cleghorn, from an area of half an acre, a quantity has been raised that would have cost $\mathfrak{L 2 5 0 0}^{2}$. if procured from St. Andrew's, after being imported thither from the shire of Augns. At Resteneth it is dug with the spade, and sold to farmers at $2 \mathrm{~d}$. the cubic foot, from two hundred and fifty to five hundred cubic feet being laid on the English acre. That which lies inmediately under the moss is reckoned the best. Some mention of the cconomical use of shell marle will be found in the Statistical Survey of Scotland, under the heads of several of the above mentioned parishes. 
the complete history of one of these accumulations. A pool of water is peopled by myriads of little animals, with whose exuviæ it becomes gradually filled, and thus beds are raised and fitted for vegetation. Water and land plants arise and decay, and in a humid soil a peat bog is formed; perhaps (as has happened at Logie) the outlet of the water is again choaked, and the same effects renew in the same order.

The calcareous beds thus formed are, it is true, on a small scale, when compared with those of the Paris or Hampshire basins. Yet contrasting the insignificance of these little testaceous animals with the space occupied by their exuvix, which at Lundie, for instance, is many feet deep and covers an area of seventy acres, the extent of their beds is surprising. The siliceous beds indeed, and the porcelanic limestone of the Paris basin are wanting to this recent formation, and are still problems for geologists to solve; but in respect of the quantity of shelly matter the analogy is perfect, and the imagination can readily seize the effects produced in a warm and prolific climate with animals of decuple dimensions, and with a liberal allowance of time.

Since shell marle is not common to all the Scotch lakes, it might be worth inquiry what peculiar circumstances favoured its production; whether calcareous salts are particularly abundant in the waters that yield it; and what are the rocks from which those waters spring, or which form the sides of containing basins. The water of Resteneth is said to be remarkably clear.

There is no limestone near to Logie, except in a small vein, distant therefrom two miles, at Readie in the parish of Airlie. The predominant rock about Resteneth is a sandstone of a brown, red, or whitish grey colour, which alternates with a coarse ferruginous pudding stone. Whin-dykes, and veins of barytic spar, occasionally tinged 
with copper, intersect this rock. From the northern edge of the loch rises a considerable hill, called Pitscanellie hill, composed entirely of grit-stone, whose different beds, alternating with a coarse breccia, furnish stones for slating, paving, mill-stones, and rubble work. From the south side of the loch rises a hill of freestone, whose summit is covered by whin. This bed of whin is of no great breadth, and extends about two miles in length, from one end of the ridge to the other. If we may guess from this description, the prevailing rock seems to be the red sandstone, so common in this island; it is in basins formed in this rock that the shell marle is found in the vicinity of Kelso.

VOL. IV. 